\title{
Meanings attributed to breastfeeding in the first two years of life: a study with women from two municipalities in the Recôncavo Baiano region of Bahia, Brazil
}

\section{Sentidos atribuídos à adoção da amamentação nos}

dois primeiros anos de vida da criança: estudo

com mulheres de dois municipios

do Recôncavo da Bahia

Franklin DEMÉTRIO'

Maria da Conceição Monteiro da SILVA²

Sandra Maria CHAVES-dos-SANTOS²

Ana Marlúcia Oliveira ASSIS²

\section{A B S T R A C T}

\section{Objective}

This study aimed to determine the maternal meanings attributed to breastfeeding during the child's first two years of life.

\section{Methods}

This qualitative, exploratory and analytical study involved mothers that participated in a cohort from a larger study done in the municipalities of Mutuipe and Laje in the Recôncavo area of the State of Bahia, Brazil. The methodological resources included thorough individual interviews and thematic analysis. The meanings were analyzed by the theoretical framework of sociological phenomenology.

\section{Results}

The meanings stated by the mothers show the singularity of breastfeeding, the importance of family, spousal and health practitioner support, and knowledge about the benefits of breastfeeding for the mother's and child's health and nutritional status.

\footnotetext{
${ }^{1}$ Universidade Federal do Recôncavo da Bahia, Centro de Ciências da Saúde, Curso de Bacharelado Interdisciplinar em Saúde. Av. Carlos Amaral, 1015, Cajueiro, 44570-000, Santo Antônio de Jesus, BA, Brasil. Correspondence to/Correspondência para: F DEMÉTRIO.E-mails:<fdemetrio@ufrb.edu.br>; <nutrifranklindemetrio@gmail.com>

2 Universidade Federal da Bahia, Escola de Nutrição, Departamento de Ciência da Nutrição. Salvador, BA, Brasil.
} 
6 | F DEMÉTRIO et al.

\section{Conclusion}

The meanings attributed to breastfeeding in the child's first two years of life reflected the influences of complex networks of social relationships of the mother's social and cultural context and of the scientific and biomedical discourse.

Indexing terms: Breastfeeding. Suckling. Child nutrition. Prenatal nutrition. Qualitative research.

\section{RE S U M O}

\section{Objetivo}

O estudo teve como objetivo desvelar os sentidos maternos atribuídos à adoção da prática da amamentação nos dois primeiros anos de vida da criança.

\section{Métodos}

Trata-se de estudo qualitativo e exploratório envolvendo mães que integraram a coorte de uma investigação mais ampla, desenvolvida nos municípios de Mutuípe e Laje, no Recôncavo da Bahia, Brasil. Utilizaram-se como recursos metodológicos a técnica da entrevista individual em profundidade e a análise temática. Os sentidos desvelados foram analisados à luz do referencial teórico da fenomenologia sociológica.

\section{Resultados}

Dentre os sentidos externalizados pelas mães, figuraram as singularidades da vivência com a amamentação, a importância do suporte familiar/cônjuge e dos profissionais de saúde e o conhecimento sobre a importância do aleitamento materno para o estado de saúde e nutrição da criança e da mãe.

\section{Conclusão}

Os sentidos atribuídos à adoção do aleitamento materno por mães nos dois primeiros anos de vida da criança refletiram influências do contexto sociocultural materno e do discurso científico-biomédico, configuradas em complexas redes de relacionamentos sociais.

Termos de indexação: Aleitamento materno. Amamentação. Nutrição infantil. Nutrição pré-natal. Pesquisa qualitativa.

\section{NTRODUCTION}

The physiological and nutritional adequacy of exclusive breastfeeding in the first 6 months and complemented from then on to at least 24 months of life for the infant's health is scientifically recognized. The use of this feeding practice is a strategy that reduces the morbidity load during childhood, ensuring the appropriate growth and development of the child ${ }^{1-3}$.

It is also recognized that the advantages of breastfeeding go beyond the biological protection provided by breast milk, and reach an economic dimension, generating positive impacts on health services, family and society ${ }^{4-7}$.

If, on the one hand, the knowledge about the benefits of breastfeeding to the health of the mother-infant dyad is consistent, on the other, the duration of this practice is short in many parts of the world, including Brazil, even though mothers often report their willingness to breastfeed as recommended by health services ${ }^{5,7-9}$.

From the viewpoint of the theoretical references about the physiology of lactation, nearly all women are capable of breastfeeding. However, this innate ability does not ensure its successful practice ${ }^{8}$. For Almeida \& Novak ${ }^{4}$, breastfeeding is a hybrid consisting of natural and cultural elements.

Hence, since breastfeeding is a psychological, biological, sociological and cultural phenomenon, and if breast milk has nutritional value, it must be emphasized that the act of breastfeeding assumes a symbolic value, and involves rituals and sociability. Therefore, it relates to senses and meanings, feelings and sensations, and the daily interpretations of experiences and/or interactions of women 
demand approaches with multidimensional foci ${ }^{4,10,11}$. Consequently, breastfeeding the child is not only an instinctive and natural act, but also represents an immanent habit to sociocultural conditioners, constituting an important theme for scientific investigation ${ }^{4,9-12}$.

For this purpose, approaches that contemplate technical information regarding the biological aspects of lactation, in addition to the subjective issues of the woman-mother perspective, are necessary for understanding the mother's choice to breastfeed. In this sense, understanding the hybridism of this phenomenon has been a challenge in the world ${ }^{1,2,9}$ and, especially, in Brazil ${ }^{4,5,7}$.

Investigation of the factors associated with early weaning has primarily focused on exclusive breastfeeding. The availability of studies that use the qualitative approach for investigating the theme "breastfeeding in the first two years of life of the child" are still scarce. This scarcity may be partly credited, in epidemiological studies, to the incipience of the sociological and anthropological approach regarding the breastfeeding phenomenon $^{4,13,14}$.

Thence, this investigation favors nearing the complex and intricate relationship that conditions the choice to breastfeed until the child is two years of age, with focus on sociocultural, economic and family factors, mother's knowledge, health services and mother's biological characteristics. Therefore, the present study aims to unveil the meanings attributed by the mother to the choice of breastfeeding during the first two years of life of the child based on a study done in two municipalities of the Recôncavo da Bahia region in Brazil.

\section{METHODS}

This qualitative, exploratory and analytical study involving mothers that participated in the broader study called "AMACOMP: Breastfeeding and complementary foods for weaning - health and nutritional status in the first two years of life of the child - a cohort study" (Amamentação e alimentação complementar no desmame - estado de saúde e nutrição nos dois primeiros anos de vida da criança - Um estudo de coorte)(3), was done in the municipalities of Laje and Mutuípe, Recôncavo da Bahia, Northeastern Brazil.

One of the axes of the study regarded a qualitative approach on breastfeeding in a birth cohort followed for two years (between March 2005 and October 2008). The municipalities of Mutuipe and Laje are located 235 and $220 \mathrm{~km}$, respectively, of Salvador, in the Region of the South Recôncavo of the State of Bahia, Brazil. Each municipality has approximately 20 thousand inhabitants, most with low income. The economy is based on family agriculture and local stores. Socioeconomic and quality of life indicators show that the two municipalities have similar Human Development Indices (HDI) (0.53 and 0.42, respectively). Additionally, the sanitary conditions of both are similar to those of other small municipalities in the State of Bahia ${ }^{15}$.

The sociological phenomenology theory proposed by Schutz ${ }^{16}$ was used for anchoring the analysis of the meanings unveiled by the study participants. This theory considers the structuring of the senses and meanings of the intersubjective experience of the interactive social relationship, knowing that subjects' actions are impregnated with contextualized meanings which are not exclusively individual but also have a social connotation. Meanwhile, the sociological phenomenology approach allows the characterization of the actions of the subjects of a social group who experience a common situation, trying to reach the phenomenon (in this case, breastfeeding) and capture/unveil its meanings to show what it is ${ }^{16,17}$.

\footnotetext{
(3) Project sponsored by the National Council for Scientific and Technological Development (Conselho Nacional de Desenvolvimento Científico e Tecnológico - CNPq), process number 505971/04-6, Center for Food and Nutrition Collaboration, Northeast Region II/MS and Research Support Foundation of the State of Bahia (Fundação de Amparo à Pesquisa do Estado da Bahia - FAPESB).
} 
This investigation randomly selected adult mothers, regardless of socioeconomic level, from urban and rural socio-spatial segments of the municipalities of Laje and Mutuípe, who breastfed their infants for 24 months or more. Mothers of premature infants, low-weight infants or infants with oral abnormalities that prevented suckling were excluded. Mothers who agreed to participate in the study signed a free and informed consent form and the illiterate provided a fingerprint.

The individual in-depth interview technique was used for data collection since it is appropriate for studying senses, meanings, aspirations, beliefs and attitudes ${ }^{18}$. The interviewers sought to obtain narratives that would allow reconstructing the symbolic universe of the mothers and a thorough analysis of the interviews involving the central issue of the study theme. The process of recurrence of the empirical categories in the interviews "saturation" criterion ${ }^{19}$-, led to closing the field phase with 15 interviews, number that allowed unveiling the meaning nuclei, foci of this investigation. The interviews followed the "nondirectiveness" principle ${ }^{20,21}$. They were guided by a number of conducive requests, such as: "Comment what the act of breastfeeding represents (or represented) to you"; "Comment how you felt about breastfeeding your child until his/her second year of age"; "Did you have any breastfeeding difficulties?"; "Did you get any support while breastfeeding your child? Discuss these supports"; "Have you been instructed by the health agent or health service to breastfeed your child? Comment"; "Can you make any comments about the importance of breastfeeding?".

The mothers were interviewed at their homes at the end of the cohort follow-up, and initially involved subjects of daily living aimed to introduce the issues related to the mothers' breastfeeding experiences. The discursive material that emerged during this process caused the unfolding of new issues that led to the next issues ${ }^{18,20}$. The researchers' impressions of the interview process and its context were written down in the field.
The interviews lasted on average 60 minutes and were taped with a tape recorder. After exhaustive listening, they were transcribed and organized into thematic categories. The interviews were codified with names of precious stones to protect the identity of the mothers.

The thematic analysis method proposed by Minayo ${ }^{18}$ was used for analyzing the interviews. This method allows discovering the "core meanings" that compose communication as their presence or frequency reveals senses and meanings of the study object. This analysis initially involved skimming the transcription in order to become familiarized with the mothers' manner of speech, and apprehend the main ideas and general meanings of the text. Next, the meaning units were selected by removing the text around each unit that guided the analysis ${ }^{18}$. Then the talk was explored and interpreted ${ }^{18}$, converging on three thematic categories as follows: a) singularities of the breastfeeding experience during the first two years of life of the child; b) family and health professional support; c) importance of breastfeeding for the health and nutritional status of the child and mother.

The study was approved by the Research Ethics Committee of the Hospital Climério de Oliveira, of the Federal University of Bahia (Universidade Federal da Bahia), under Protocol $n^{\circ} 74 / 2005$.

\section{RESULTS AND DISCUSSION}

\section{Demographic, socio-spatial, environmental and obstetric characterization of the study subjects}

Fifteen mothers participated in this study, 10 from Mutuípe and 5 from Laje. Their mean age was 26 years $( \pm 4.89)$. Fourteen of these mothers lived with a partner. Among them, 9 lived in urban areas and 6 in rural areas, thus representing two socio-spatial segments. Four mothers who lived in rural areas had low education level (less than seven years of formal 
education). In relation to their living conditions, 8 mothers lived in unsanitary homes (without sewage), 5 of them located in rural areas. All mothers reported having attended prenatal care, where 5 of them received some breastfeeding instructions. Nine mothers attended 6 or more prenatal care visits. All mothers reported receiving nutritional instructions for themselves and their child, both in the hospital and during follow-up (data not tabulated).

\section{Unveiling the maternal meanings attributed to the choice of breastfeeding}

The three thematic categories delineated in this study are discussed below.

\section{Singularities of the breastfeeding experience during the first two years of life of the child}

For the interviewees, the breastfeeding experience was marked, on the one hand, by satisfaction, affection, motivation and pleasure, and on the other hand, by difficulties, especially difficulties related to the management of the breasts and the increased amount of work that caring for the child required. However, the difficulties were overcome by persistence and desire to breastfeed, as one can infer from the content of their testimonies.

...much happiness and like... . I felt very happy by breastfeeding my child... it is very good to give the child something you produce, right?... (Turquoise, urban area).

...some mothers breastfeed because breastfeeding is necessary ...but I think that, when the mother breastfeeds with love, the love goes to the child... I felt this... if we are breastfeeding with all our heart, the child feels it through the milk... because I enjoyed breastfeeding all my girls, so much that they only stopped breastfeeding at two years of age... and because they were already very big so I decided to wean them quickly (Ruby, rural area).

...I felt a lot of pain... right when I first started breastfeeding I wanted to stop breastfeeding... but with her (second child), it hurt less... with the first, the person is not used to it, but on the second child, it is going to hurt, but it is not like the first child... but when I was breastfeeding my second child I thought about stopping too... it's that when her teeth were erupting I thought about stopping and stayed with that discomfort... but she was already about one year something when her teeth started erupting and then I felt that agony, then I started getting used to it... then I breastfed until she was two... (Amethyst, urban area).

... actually it was difficult only at night... I used to get up frequently during the night to breastfeed, I had to breastfeed all the time... during the day I stopped during the right times that he wanted... but I did not give up... . I only stopped breastfeeding when he was two years and three months old since he was already starting to eat (Pearl, rural area).

Breastfeeding was clearly also linked to previous positive experiences and to the family's breastfeeding experience for mothers of both socio-spatial segments:

I breastfed all my children more than two years... breastfeeding is a family thing, my grandmother breastfed my mother, my mother breastfed me and my siblings, this is very important, we learn very early that we have to breastfeed our children... (Diamond, urban area).

...I saw my older sister who had a child before me breastfeed, I saw my cousins... . I was breastfed, so were my sisters, so we grow up seeing it... we learn and become 
captivated and I believe this helped me to breastfeed my child... (Brilliant, rural area).

It is understood that each mother experiences breastfeeding in a unique manner, and attributes to the practice meanings according to her own social trajectory. Schutz ${ }^{16}$ and Boltanski22 pointed out that, although the singularities are personal, they are reconfigured in consonance with a set of classifying sociocultural categories that have collective constructs.

Hence, from the sociological phenomenology viewpoint ${ }^{16}$, it is possible to understand that the experience of the mother with breastfeeding is a sociocultural praxis, that is, an interactive process with her family and social everydayness, which confers dynamism to the concepts shared intersubjectively among women who breastfeed, and thereby guide the resignification of their knowledge, attitudes and practices.

In this sense, approaching breastfeeding as a phenomenon allows the actors involved to apprehend the actual experience of the mothers as the starting point for their professional activity. The actors try to understand the interrelationships that exist between the context in which they occur and the experiences constructed in the mother's social universe $\mathrm{e}^{16,17}$, which then allows them to develop an integral and humane care to lactating women ${ }^{23}$.

Although breastfeeding is scientifically legitimated as being easy and pleasing, that all women are anatomically and physiologically capable of performing ${ }^{24}$, there are other aspects - such as meanings, beliefs and taboos in the individual and social maternal imagery - that conform to a network of signs that may affect this practice. Therefore, it is understood that these women's experiences with breastfeeding imply the involvement of many reasons and factors that do not depend exclusively on knowing about breastfeeding benefits and techniques, or on a previous decision ${ }^{17,24}$. Therefore, these reasons and factors need to be considered for the technical and practical breastfeeding success.
On the other hand, having had a successful breastfeeding experience in the past encourages women to breastfeed the next child for a longer period of time, as found by the present study. Something similar is reported by Fujimori et al. regarding mothers from the state of São Paulo ${ }^{25}$.

It is possible that events experienced by women during childhood and the primary socialization process be remembered as latent meanings that emerge when they retrieve expressive aspects for understanding the desire to breastfeed ${ }^{20}$. Hence, it is understood that the practice of breastfeeding, although instinctive, requires systematic and continuous learning by the mother.

From a historical and cultural viewpoint, successful breastfeeding qualifies the mother's performance as an important social and family meaning in the woman's life, without disregard for the biological factors that can be expressed by difficulties in managing the breasts, for example lacerations, and suckling difficulties ${ }^{11}$. In the present study, breastfeeding depended on the mother's ability to overcome these hardships for the sake of the desire to breastfeed, as a result of the direct relationship between breastfeeding and maternal love.

\section{Family and health professional support}

The participation of the family members in the breastfeeding process, especially of the grandmothers and spouse or partner, was a factor that favored breastfeeding, since the family helped to care for the child and with the house chores.

I have always been supported by my husband, my mother, my sisters, my mother-in-law... they told me that I should give my child plenty of breast milk because it would be good for me and for my son, so they kept encouraging me to breastfeed and help everything go well, so I did it... they helped me to care for my child and for the house... and this really 
helped me to breastfeed my child... (Emerald, rural area).

I had support from my husband who always told me that it was right to breastfeed, meanwhile my mother, who is older, she did not agree, she said that when the child cried a lot it was because the child was hungry, that I had to give something else that the boy was hungry, but I did not think so... this is so correct that to this day, when I see some girls coming to me saying "oh, I am going to give some other thing because the boy is hungry", I say "but it is not necessary because breast milk alone is already enough for him", then they say "oh, not if the boy is crying, it means he is hungry", I do not think they are right... (Opal, urban area).

Support from the spouse/partner appeared as contributing factor for continued breastfeeding until the second year of age of the child, especially when the spouse effectively participated in the daily care of the woman and child. When the partner shares child-related chores, his participation is understood by the woman as "marital commitment" regardless of residence location, rural or urban. For Machado \& Bosi ${ }^{20}$, this behavior gives the father the chance to care for the child, encouraging him to feel breastfeeding not only as something exclusive of the mother, but also as the sharing of responsibilities to be assumed by the couple in the midst of family relationships.

In this study, the family helped the mother to be the breastfeeding protagonist, and helped her to recognize the co-participation of other people, for example, the spouse, who provides daily help while the mother breastfeeds.

Barreira \& Machado ${ }^{26}$ consider the family as the first and most important group unit that defines the behaviors displayed by individuals. On the other hand, social transformations affect the way individuals assume their roles inside the family unit. Hence, modern lifestyles reconfigure traditions and promote different attitudes in face of the difficulties faced by the members of the family, inducing new arrangements in the family structure $^{26}$. In this scenario, the family significantly exercises the mother's decision to breastfeed.

In the context of these changes, for some decades during the Twentieth Century, women were greatly influenced by the social marketing done by the food industry, especially by infant formula manufacturers who encouraged early weaning by arguing in advertisements that breast milk is weak, pointing out its supposed inability to meet the nutritional needs of the child. These advertisements contextualized breastfeeding as the factor responsible for ptosis (sagging breasts), among other unfavorable aspects ${ }^{10,20}$. These facts encouraged the creation of a generation of women who discredited breast milk as a satisfactory source of nutrients for the child ${ }^{10}$. Since many of these women from different sociospatial segments are grandmothers today, they tend to transmit this information to the new generations, as can be seen in the narration provided by Opal, who lives in an urban area: "meanwhile, from my mother's side, since she is older, she denied... she said that when the child cried too much it was because the child was hungry, that I had to give something else... that only my milk was not enough". This aspect was relevant among the mothers living in urban areas.

According to Assis et al. ${ }^{27}$, the worldview of rural groups is a positive factor for the preservation of healthy life practices and conservation of a supportive living state. In this perspective, one can see that the study mothers in rural areas breastfed for longer periods than those in urban areas, although scientific evidences indicate that the change in breastfeeding pattern is not exclusive of mothers living in urban areas 8, 14,27,28. Maybe this fact expresses the phenomenon of smaller differences between rural and urban life in these municipalities. This mode of life suggests that breastfeeding is a dynamic process that has been undergoing the influences of the social transformations imposed by economic development. 
The extent of modernization and urbanization may also change, to a greater or lesser degree, the global breastfeeding patter $n^{1,27,27,28}$. Regardless, population or family groups manage to remodel the difficulties imposed by new social modes of life and create a positive pattern of adoption of healthy practices, including breastfeeding.

In the landscape of the priority actions for promoting breastfeeding, the information and advice coming from health professionals or closer people stand out as an important social support element that encourages the study mothers to breastfeed and do so for extended periods.

...health professionals told me that breast milk was good for the child. Meanwhile, some people in the streets told me it was good and others told me it was foolish to give only breast milk until the sixth month, that I would only get very stressed, that it would be more correct to offer food as soon as the child was 2 or 3 months old... but most people told me to continue breastfeeding... (Amethyst, urban area).

... what I learned when I went to the hospital to have my child... what I was told is that it was important to give only breast milk until the child was 6 months old... but this child was exclusively breastfeed for 5 months ....but / continued to breastfeed her until she was 3 years old because the dietician always said that it was good to breastfeed so I continued breastfeeding... (Sapphire, rural area).

The counseling role of health professionals regarding breastfeeding is indubitable, as shown by the results of the present and other studies ${ }^{9,14,20,29}$. However, results from other studies indicate that some health professionals have considered breastfeeding to be a purely instinctive and biological act. This concept suggests the need of broadening and reformulating the technical view on breastfeeding $4,10,23,30$. In this sense, for effective breastfeeding assistance, it is necessary to consider the dynamism of the mothers' demands and expectations, emphasizing the importance of understanding the singular and plural universe of women and connecting information in order to support her in this process.

The opinions and advice stemming from health professionals have also provided elements that influenced the mother's assessment of the nutritional status of the child, especially about the ability of breast milk to meet the growth and development requirements of the child.

I felt an imense (emphasis) pleasure... in watching him suckle... watching him develop, especially when I went to the healthcare facility to weigh him and the dieticians said that his weight was excellent, that he was growing and developing very well, then I got very happy indeed... and I saw that he was well... that only made me want to breastfeed him more and more... (Opal, urban area). I learned from the dieticians that I should only give my child breast milk until the sixth month of age because breast milk has everything that the child needs... . I only weaned him at the age of two years and four months because he no longer wanted to suckle... (Alexandrite, rural area).

The meanings attributed by the mothers to formal and informal support, contextualized in successful breastfeeding, also stood out among mothers from other Brazilian realities ${ }^{20}$ and in the international landscape ${ }^{14,29}$. Results of a qualitative study ${ }^{14}$ done with Spanish mothers aiming to grasp their perceptions of formal and informal breastfeeding support indicated that spousal, family, health professional and employer support strongly influenced their decision to breastfeed.

The conflict caused by practices that discourage breastfeeding must also be highlighted. In this sense, inappropriate information coming from other social networks, especially friends, neighbors and relatives, may impact the decision to breastfeed, as can be noticed in Amethyst's 
testimony (urban area): "Meanwhile, some people in the streets told me it was foolish to give only breast milk until the sixth month, that I would only get very stressed, that it would be more correct to offer food as soon as the child was two or three months old...". The results of the study by Fujimori et al. ${ }^{25}$ involving mothers who use public health services in the state of São Paulo corroborated this finding. The authors observed that the grandmother, mother-in-law, sisters, sisters-in-law, spouse, neighbor or people with more experience influenced the practice of breastfeeding, and, in an attempt to help resolve the doubts and uncertainties of the mother, they could end up encouraging weaning.

Given the exposed information, the strategies that encourage breastfeeding should involve not only mothers, but also the distinct social networks that imprint multiple meanings to the act of breastfeeding.

\section{The importance of breastfeeding for the health and nutritional status of the child and mother}

The reports of the mothers showed that in addition to understanding the importance of the immunological and nutritional factors present in breast milk for disease prevention and the growth and development of the child, expressing the influence of the scientific and biomedical discourse, facts about the role of breastfeeding for establishing the mother-infant bond also came up.

...ah, I believe we should breastfeed because breast milk is good for the development of the child and also for avoiding many diseases. I feel good when I am breastfeeding, I feel that I get closer to the child... (Pink quartz, rural area).

...breastfeeding is good because it makes the child healthy, it works like a vaccine, it is good for the child's growth, it is good for the mother because when the mother is breastfeeding, it helps her body go back to normal... there is a lot of weight loss ...

(Diamond, urban area).

...breastfeeding was no work at all... it was good, right?... because it avoided certain types of diseases... thank God until now they never had to be hospitalized... some mothers do not breastfeed because they are mean and this and that... not until now... they were all breastfed, and I felt good for having breastfed my child for a long time... . I also never got sick, thank God... it was good for my health too... . I did not have to buy tons of milk (Sapphire, rural area).

The energy and nutrient content of breast milk is adequate for the physiological immaturity of the infant, and its ability to protect against gastrointestinal and respiratory diseases make breast milk the ideal food capable of meeting the nutritional needs of the infant, especially during the first months of life of the child and promote the child's full development $1,3,5,7,31$. Some health professionals cite these biological factors and many contents disclosed by the media, making explicit the benefits of breastfeeding and evident the preventive aspects for the child7,10,12. It is possible that these contents and aspects are internalized by the mothers as an important event for the nourishment and health of their children. This became evident at the beginning of the 1980s, with the creation of the National Breastfeeding Promotion Policy (Politica Nacional de Incentivo ao Aleitamento Materno - PNIAM), when the competent institutions began a process of regulating and controlling advertisements and sales of modified milks and infant formulas, previously called "maternalized" 7,10 .

In this study, the interviewees considered breast milk to be important not only for the health of the child from the biological, nutritional and psychological (mother-child bond, for instance) point of views, but also for their own health and nutrition status. Breastfeeding also helped the mothers shed weight after delivery and mitigated the expenses. 
The benefits associated with breastfeeding for women's health are scientifically recognized: protection against breast and ovarian cancer, osteoporosis-associated fractures, risk of rheumatoid arthritis, loss of the weight gained during pregnancy during the puerperium, increased duration of lactational amenorrhea and contraceptive effect, especially during exclusive breastfeeding, faster uterine involution, reduced blood loss during delivery, lower risk of postpartum depression, and low incidence of cardiovascular diseases after menopause ${ }^{7,31}$.

Therefore, the maternal meaning of breastfeeding gains epidemiological and social relevance as it guides strategies and policies that focus on its benefits for the woman's health and nutrition and for the child. However, the biomedical discourse used by health professionals still focuses on the infant, followed by justifications such as "it is important for the child" or "it is better for the child," indicating that the focus of breastfeeding advice is the child and the child's health and nutritional needs. The woman, her health, her pleasure and her rights remain invisible in the context of breastfeeding promotion and encouragement ${ }^{9}$. In the present study, this aspect emerges in the speech of the interviewee Emerald, who lives in a rural area:

...this is what I think, that it is good for the child, right... the child grows up healthier, as she (the dietician) said that breast milk prevented many diseases... flu, diarrhea... that it was better for her to be breastfed... but I learned that breast milk protected her from many diseases... the benefit was indeed for the child... .

Given the above, it is important for health professionals to extend their technical breastfeeding actions beyond biological and procedural aspects and also consider the mothers' settings as well as their cultural backgrounds. Furthermore, health professionals should try to establish sufficient dialogue and listen to women who breastfeed, understand the importance of breastfeeding for them and their children, in order to effectively contribute to the success of this practice, as recommended by the World Health Organization ${ }^{1}$ and Ministry of Health ${ }^{5}$.

It is essential to point out that the phenomenological focus taken by this study allowed understanding lactating women as a being in the world, a being who is simultaneously cast, present and felt present in social macro- and microstructures $^{32}$. In other words, the act of women who breastfeed is conscious, and focuses on someone or something. It assumes multiple meanings constructed from an interactive involvement with many people and contexts, in complex networks of social relationships ${ }^{16,17}$.

\section{CONCLUSION}

In the present study, successful breastfeeding until the second year of age of the child was associated with the mothers' meanings of breastfeeding. These meanings were constructed from their life experiences and their interactions with health professionals and services, from whom they learned and resignified concepts about this practice in consonance with sociocultural, scientific, economic and political transformations. Hence, the mothers' meanings attributed to the act of breastfeeding during the first two years of life of the child reflected influences of sociocultural factors and of the scientific and biomedical discourse.

The singularities associated with the breastfeeding experience are among the meanings externalized by the mothers who breastfed their children until the second year of age, the importance of family/spousal support and that of health professionals, and the knowledge on the importance of breastfeeding for the health and nutritional status of the child and mother.

The results of this study allow the realization that the act of breastfeeding is, for women, a process of continued learning, which is based on the distinct and diverse interactions of their daily life experiences. And therefore, the success of this practice depends on the strategies 
used by health services before and after delivery that consider widening the reception spaces, listening and dialogue for the integral care of the pregnant/lactating woman. Furthermore, these strategies should involve the family in breastfeeding counseling, encouraging and appreciating the family for their participation and collaboration in supporting maternity, for the effective implementation of breastfeeding until the second year of the child's life. The importance of the sensible and strategic involvement of healthcare professionals, friends and neighbors is also noteworthy for effective breastfeeding promotion and encouragement.

In this sense, it is hoped that the reflections stemming from this study allow a broader understanding of the factors that affect breastfeeding during the first two years of life from the mother's viewpoint, in order to support professional practice and the planning and (re)assessment of public policies in the field of mother-infant health and nutrition.

\section{A C KNOWLEDGMENTS}

We thank the mothers for having contributed with their precious reports; Conselho Nacional de Desenvolvimento Científico e Tecnológico, Fundação de Amparo à Pesquisa do Estado da Bahia and the Centro Colaborador em Alimentação e Nutrição Nordeste II - Ministry of Health, for sponsoring the study; and the Nutritional Epidemiology Nucleus of School of Nutrition - Universidade Federal da Bahia, for the technical and scientific support.

\section{COLLABORATORS}

F DEMÉTRIO conceived the article and participated in data collection and interpretation, and writing and revision of all the stages of the manuscript. MCM da SILVA helped to collect the data and write the manuscript. SMC dos SANTOS critically revised the article and helped to write it. AMO ASSIS conceived the study, obtained a grant, coordinated the major investigation from which this article derived, helped to conceive the design of the article, participated in data collection, collaborated with the writing and critically revised the manuscript during all stages of its development.

\section{REFERENCES}

1. World Health Organization. Indicators for assessing infant and young child feeding practices. Conclusions of consensus meeting held 6-8 November 2007. Washington (DC): WHO; 2007.

2. United Nations Children's Fund. Baby friendly initiative. The effectiveness of baby friendly accreditation in increasing breastfeeding rates. London: UNICEF [cited 2010 Oct 23]. Available from $<$ http://www.unicef.org.uk/BabyFriendly/Newsand-Research/Research/Baby-Friendly-Initiative/ Baby-Friendly-accreditation-increasesbreastfeeding-rates/>.

3. Martins EJ, Giugliani ER. Which women breastfeed for 2 years or more? J Pediatr. 2012; 88(1):67-73.

4. Almeida JAG, Novak FR. Amamentação: um híbrido natureza-cultura. J Pediatr. 2004; 80(Supl 5): S119-S25.

5. Brasil. Ministério da Saúde. Secretaria de Atenção à Saúde. II Pesquisa de prevalência de aleitamento materno nas capitais brasileiras e Distrito Federal. Brasília: MS; 2009.

6. Baptista GH, Andrade AHHKG, Giolo SR. Fatores associados à duração do aleitamento materno em crianças de famílias de baixa renda da Região Sul da cidade de Curitiba, Paraná, Brasil. Cad Saúde Pública. 2009; 25(3):596-604.

7. Caminha MFC, Serva VB, Arruda IKG, Batista Filho M. Aspectos históricos, científicos, socioeconômicos e institucionais do aleitamento materno. Rev Bras Saúde Matern Infant. 2010; 10(1):25-37.

8. Demétrio F, Pinto EJ, Assis AMO. Fatores associados à interrupção precoce do aleitamento materno: um estudo de coorte de nascimento em dois municípios do Recôncavo da Bahia, Brasil. Cad Saúde Pública. 2012; 28(4):641-54. doi: 10.1590/S0102-311X2 012000400004

9. Schmied V, Beake S, Sheehan A, McCourt C, Dykes F. Women's perceptions and experiences of breastfeeding support: a metasynthesis. Birth. 2011; 38(1):49-60. doi: 10.1111/j.1523-536X.2 01 $0.00446 . x$

10. Bosi MLM, Machado MT. Amamentação: um resgate histórico. Cad ESP. 2005; 1(1):17-25.

11. Araújo RMA, Almeida JAG. Aleitamento materno: o desafio de compreender a vivência. Rev Nutr. 2007; 20(4):431-8. doi: 10.1590/S1415-527320 07000400010 . 
12. Sandre-Pereira G, Colares LGT, Carmo MGT, Soares EA. Conhecimentos maternos sobre amamentação entre puérperas inscritas em programa de pré-natal. Cad Saúde Pública. 2000; 16(2):457-66.

13. Trostle JA. Epidemiology and culture. Cambridge: University Press; 2005.

14. Barona-Vilar C, Escribá-Aguir V, Ferrero-Gandía R. A qualitative approach to social support and breastfeeding decisions. Midwifery. 2007; 25(2):187-94. doi:10.1016/j.midw.2007.01.013.

15. Instituto Brasileiro de Geografia e Estatística. IBGE cidades. Brasília: IBGE [acesso 2008 ago 31]. Disponível em: <http://www.ibge.gov.br/cidadesat/ topwindow.htm?1>.

16. Schutz A. Fenomenologia e relações sociais. Rio de Janeiro: Zahar; 1979.

17. Souza MHN, Souza IEO, Tocantins FR. Abordagem da fenomenologia sociológica na investigação da mulher que amamenta. Rev Enferm UERJ. 2009; 17(1):52-6.

18. Minayo MCS. O desafio do conhecimento: pesquisa qualitativa em saúde. $12^{\mathrm{a}}$ ed. São Paulo: Hucitec; 2010.

19. Fontanella BJB, Luchesi BM, Saidel MGB, Ricas J, Turato ER, Melo DG. Amostragem em pesquisas qualitativas: proposta de procedimentos para constatar saturação teórica. Cad Saúde Pública. 2011; 27(2):389-94. doi: 10.1590/S0102-311X20110 00200020.

20. Machado MMT, Bosi MLM. Compreendendo a prática do aleitamento exclusivo: um estudo junto a lactantes usuárias da Rede de Serviços em Fortaleza, Ceará, Brasil. Rev Bras Saúde Matern Infant. 2008; 8(2):187-96.

21. Kandel L. Reflexões sobre o uso da entrevista, especialmente a não-diretiva, e sobre as pesquisas de opinião. In: Thiollent MJM. Crítica metodológica, investigação social e enquete operária. $5^{a}$ ed. São Paulo: Polis; 1987.

22. Boltanski L. As classes sociais e o corpo. Rio de Janeiro: Graal; 1989.

23. Demétrio F, Paiva JB, Fróes AAG, Freitas MCS, Santos LAS. A nutrição clínica ampliada e a huma- nização da relação nutricionista-paciente: contribuições para reflexão. Rev Nutr. 2011; 24(5):663-796. doi: 10.1590/S1415-52732011000500008.

24. Nakano AMS. As vivências da amamentação para um grupo de mulheres: nos limites do ser "o corpo para o filho" e de ser "o corpo para si". Cad Saúde Pública. 2003; 19(Supl 2):S355-S63.

25. Fujimori E, Nakamura E, Gomes MM, Jesus LA, Rezende MA. Aspectos relacionados ao estabelecimento e manutenção do aleitamento materno exclusivo na perspectiva de mulheres atendidas em uma maternidade básica de saúde. Interface. 2010; 14(33):315-27.

26. Barreira SMC, Machado MFAS. Amamentação: compreendendo a influência familiar. Acta Scientiarum Health Sci. 2004; 26(1):11-20.

27. Assis AMO, Prado MS, Freitas MCS, Silva RCR, Ramos LB, Machado AD. Prática do aleitamento materno em comunidades rurais do semi-árido baiano. Rev Saúde Pública. 1994; 28(5):380-4.

28. Lynch S, Bethe J, Chowdhury N, Moore JB. Rural and urban breastfeeding initiation trends in lowincome women in North Carolina from 2003 to 2007. J Hum Lact. 2012; 28(2):226-32. doi:10.117 7/0890334411430086.

29. Moussa Abba A, De Koninch M, Hamelin AM. A qualitative study of the promotion of exclusive breastfeeding by health professionals in Niamey, Niger. Inter Breastfeeding J. 2010; 5(8):1-7. doi:10.1 186/1746-4358-5-8.

30. Leite AM, Silva IA, Scochi CGS. Comunicação nãoverbal: uma contribuição para o aconselhamento em amamentação. Rev Latino-Am Enfermagem. 2004; 12(2):258-64.

31. American Academy of Pediatrics. Breastfeeding and the use of human milk. Pediatrics. 2012; 129(3): 827-41.

32. Silva JMO, Lopes RLM, Diniz NKF. Fenomenologia. Rev Bras Enferm. 2008; 61(2):254-7.

Received on: 21/3/2012

Final version on: 5/7/2012 Approved on: 20/8/2012 